\title{
SIFAT FISIK IJUK DAN POTENSINYA SEBAGAI PERINTANG FISIK SERANGAN RAYAP TANAH
}

\author{
Physical Characteristics of Sugar-Palm Tree Fiber and Its Potency as a Physical Barrier \\ Against Subterranean Termites
}

Astuti Arif, Musrizal Muin, dan Syahidah

\begin{abstract}
The fiber of sugar-palm tree Arenga pinnata Merr., locally known as ijuk, is traditionally used as covering to protect ground-contact wood construction materials although effectiveness of the material in protecting wood construction from biodeterioration has not been determined. In the current study, potential of the sugar-palm tree fiber as a physical barrier against termite attacks was analyzed in terms of their structure and physical characteristics. Samples of sugar-palm tree fibers from natural and marketed formations were prepared and determined for their fiber distribution, shapes, sizes, moisture content, density, and sheet grammage since these aspects were considered to be important factors influencing the penetration ability of termites. Results showed that each of the sugar-palm tree fibers has different shapes (half-round, round, rectangle) and different sizes (ranging from 0.05 to $1.00 \mathrm{~mm}$ in thickness). It was also found to have 3-5 ramifications with the angle of $10^{\circ}-30^{\circ}$. The process of branching out was supposed to initiate a natural insertion of each formed fiber to others. It is believed that fibers with particular arrangements are able to prevent the penetration or tunneling of termites.
\end{abstract}

Key words: Sugar- palm tree fiber, physical barrier, subterranean termites

\section{PENDAHULUAN}

Penelitian-penelitian tentang pengendalian serangan rayap tanah pada bangunan telah berkembang sejak organisme tersebut digolongkan ke dalam kelompok perusak kayu bangunan dan bahan berlignoselulosa lainnya yang secara ekonomis sangat merugikan dan mengancam sumberdaya hutan (Rakhmawati, 1996). Pada dasarnya, serangan rayap tanah dapat dicegah dengan membuat lapisan yang dapat mengisolasi secara penuh semua kayu bangunan dari permukaan tanah karena dalam melakukan serangan, rayap tersebut selalu mempertahankan kontak dengan tanah. Dewasa ini, usaha-usaha untuk mencegah serangan rayap dapat dilakukan dengan memasukkan bahan kimia pengawet ke dalam struktur kayu yang digunakan atau dengan memanfaatkan bahan perintangan fisik (physical barrier).

Penelitian perintangan fisik berkembang pesat sebagai suatu alternatif pengganti perlakuan bahan kimia terhadap tanah bangunan (soil treatment). Dalam hal ini, penggunaan perintang fisik akan bersifat lebih ramah lingkungan dibanding dengan penggunaan bahan kimia yang dapat menimbulkan dampak negatif, baik terhadap manusia maupun terhadap lingkungannya. Namun demikian, perkembangan penggunaan perintang fisik hingga saat ini masih berorientasi pada penciptaan struktur atau produk baru yang didesain secara khusus menggunakan bahan baku baja atau tembaga, teknik instalasi yang ketat, dan mahal. Padahal secara prinsip, serangan rayap tanah dapat saja diisolasi dari bangunan dengan menggunakan suatu lapisan pembatas yang sifat dasarnya dapat menyebabkan rayap tidak mampu melewati ruang yang tersedia atau tidak mampu membuat ruang yang dapat dilalui akibat sulitnya mengangkat/memindahkan bahan pembatas tersebut. Penelitian ini dilakukan untuk menentukan potensi penggunaan ijuk sebagai perintang fisik serangan rayap tanah berdasarkan struktur dan sifat fisiknya, baik dalam formasi alami maupun dalam formasi pasarannya. Hal ini didasari oleh pengetahuan dan keyakinan masyarakat lokal bahwa bangunan kayu akan menjadi tahan lama apabila bagian kayu yang berhubungan dengan tanah dibungkus dengan ijuk. 


\section{BAHAN DAN METODE}

\section{Persiapan Bahan ljuk}

Bahan berupa ijuk diambil dari pohon aren (Arenga pinnata Merr.) yang tumbuh secara alami (natural formation) dan dari pasar (marketed formation). Bahan dari formasi alami yang dijadikan contoh uji dipanen dari bagian pohon aren yang tidak berpelepah dan dijaga agar tetap dalam bentuk alaminya, sedangkan bahan dari formasi pasarannya disiapkan sesuai dengan keadaan gulungannya dan dihamparkan pada saat pengambilan contoh uji. Contoh uji berukuran 30 $\mathrm{cm} \times 30 \mathrm{~cm}$ dari setiap formasi tersebut dibuat masing-masing dengan tiga ulangan. Setiap contoh uji tersebut kemudian dibagi dua bagian dengan ukuran yang sama $(30 \mathrm{~cm} \times 15 \mathrm{~cm})$ yang masingmasing digunakan untuk analisa struktur dasar dan sifat fisik ijuk.

\section{Penentuan Struktur ljuk}

Struktur dasar ijuk yang meliputi susunan, jarak antara serat penyusun, dan bentuk serta ukuran serat penyusun jaringannya dianalisa pada setiap sampel uji yang telah disiapkan. Susunan jaringan ditentukan secara makroskopis dan mikroskopis dengan mengamati sudut perpotongan antara serat-serat penyusun jaringan ijuk. Jarak antara serat-serat penyusun dihitung dengan mengukur jarak antara serat asal dengan serat percabangannya setelah serat tersebut dipisahkan dari jaringannya secara hati-hati menggunakan pinset. Untuk tujuan pengukuran tersebut, sebanyak 15 sampel serat diambil secara acak. Di samping itu, bentuk dan ukuran serat penyusun jaringan, mulai dari serat asal/induk hingga percabangan terakhirnya, juga diamati secara mikroskopis.

\section{Penentuan Sifat Fisik ljuk}

Sifat fisik ijuk yang diamati meliputi kadar air dan kerapatan serat penyusun serta gramatur lembarannya. Kadar air dan kerapatan contoh uji ijuk diukur pada kondisi kering udara sesuai dengan kondisi pengamatan strukturnya. Pengukuran berat ijuk dilakukan dengan menggunakan timbangan digital (ketelitian 0,01), sedangkan pengukuran volumenya dilakukan dengan metode celup dan penimbangan berat air yang dipindahkan menggunakan alat timbangan yang sama. Gramatur jaringan serat ditentukan berdasarkan perbandingan berat jaringan dengan luasnya.

\section{Analisis Data}

Seluruh data yang diperoleh diuraikan secara deskriptif. Untuk mengetahui potensinya sebagai bahan perintang fisik, hasil yang diperoleh mengenai struktur dan sifat fisik ijuk tersebut dibandingkan dengan hasil penelitian terdahulu menyangkut penggunaan bahan perintang fisik lainnya.

\section{HASIL DAN PEMBAHASAN}

\section{Struktur ijuk}

Hasil pengamatan menunjukkan bahwa ijuk formasi alami maupun ijuk pasaran memiliki susunan jaringan yang terdiri atas serat-serat dengan ukuran yang berbeda dan saling berhubungan satu sama lain. Bentuk dan ukuran serat penyusun dari kedua formasi ijuk tersebut dapat dilihat pada Tabel 1.

Hubungan antara serat yang satu dengan serat lainnya dapat berupa percabangan serat (ramification) dan berupa jalinan serat (insertion)

Table 1. Shapes and sizes of the composed fibers of ijuk

\begin{tabular}{|c|c|c|c|c|}
\hline \multirow{3}{*}{ Ramifications } & \multicolumn{4}{|c|}{ Fiber shapes and sizes } \\
\hline & \multicolumn{2}{|c|}{ Natural Formation } & \multicolumn{2}{|c|}{ Marketed Formation } \\
\hline & Shape & Size $(\mathrm{mm})$ & Shape & Size $(\mathrm{mm})$ \\
\hline $1^{\text {st }}$ & Half-round - Rectangle & 0.98 & Half-round - Rectangle & 0.93 \\
\hline $2^{\text {nd }}$ & Round & 0.35 & Half-round - Round & 0.40 \\
\hline $3^{\text {th }}$ & Round & 0.28 & Half-round - Round & 0.40 \\
\hline $4^{\text {th }}$ & Round & 0.16 & Half-round - Round & 0.38 \\
\hline $5^{\text {th }}$ & Round & 0.07 & Half-round - Round & - \\
\hline
\end{tabular}


dengan sudut perpotongan berkisar $10^{\circ}-30^{\circ}$ (Gambar 1). Percabangan serat tersebut dapat mencapai turunan cabang ke lima pada ijuk formasi alami, tetapi percabangannya hanya sampai ke empat pada ijuk formasi pasaran. Hasil pengamatan juga menunjukkan bahwa jarak antar cabang pertama dengan cabang berikutnya berbeda-beda seperti dapat dilihat pada Tabel 2 .

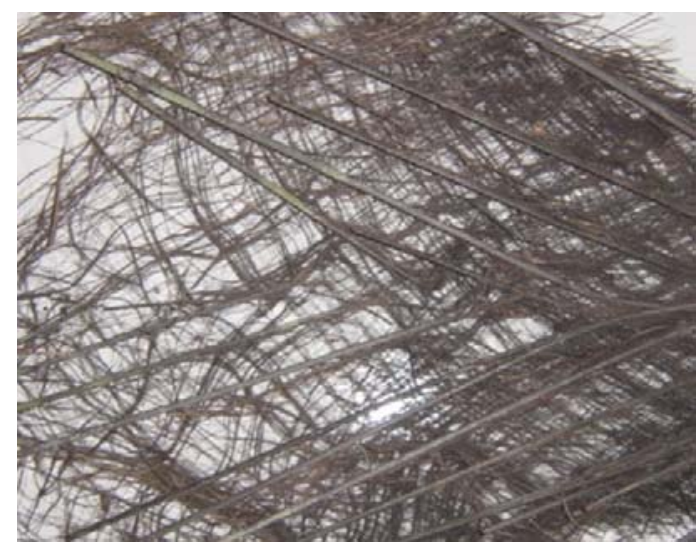

Figure 1. Orientation of fibrous elements within the separated layer of natural formation

\section{Sifat Fisik ljuk}

Rata-rata dan standar deviasi kadar air ijuk formasi alami dan formasi pasaran masing-masing adalah $16,54 \pm 1,64 \%$ dan $10,29 \pm 1,39 \%$. Sifat fisik ijuk seperti kerapatan dan gramatur juga agak berbeda menurut sumbernya (alami atau pasaran). ljuk formasi alami memiliki rata-rata kerapatan dan gramatur masing-masing $1,001 \mathrm{~g} / \mathrm{cm}^{3}$ dan 472,663 $\mathrm{g} / \mathrm{m}^{2}$, sedangkan ijuk formasi pasaran memiliki rata-rata kerapatan dan gramatur masing-masing $0,997 \mathrm{~g} / \mathrm{cm}^{3}$ dan $484,587 \mathrm{~g} / \mathrm{m}^{2}$. Lebih rendahnya rasio nilai gramatur lembaran dan kerapatan ijuk dalam formasi alaminya menunjukkan bahwa ijuk formasi alami bersifat lebih kompak dibanding dengan formasi pasarannya. Namun demikian, nilai kekompakan ini terutama setelah dipanen (formasi pasaran) dapat diatur dan dimodifikasi melalui proses pembentukan lembaran yang lebih seragam. Hal ini dimungkinkan karena struktur serat penyusunnya yang bercabang dan dapat saling menjalin seperti diuraikan terdahulu.

Hasil penelitian terhadap kelayakan beberapa tipe partikel sebagai perintang fisik serangan rayap tanah yang telah dilakukan oleh Yanase et al. (2005), menunjukkan bahwa bentuk dan sifat permukaan dari partikel dapat mempengaruhi perilaku penetrasi rayap tanah. Partikel yang berbentuk bulat dapat mencegah rayap menembus celah antar partikel karena mempunyai kekompakan yang tinggi. Selain itu, sifat permukaan partikel seperti permukaan yang halus dapat mencegah serangan rayap tanah karena hal ini akan menyulitkan rayap dalam mengangkat/memindahkan partikel dimana rayap akan mudah tergelincir. Hasil penelitian lapangan yang dilakukannya menunjukkan bahwa, lapisan palletized-stone powder dengan panjang 2,00 $3,35 \mathrm{~mm}$ dan crushed glass dengan panjang 1,00 - 2,80 mm dapat mencegah penetrasi rayap tanah selama enam bulan. Di samping faktor bentuk, ukuran, dan kehalusan permukaan, berat partikel juga dapat mempengaruhi penetrasi rayap. Menurut Tarmadi dan Yusuf (2004), partikel yang lebih ringan dapat lebih mudah dipindahkan oleh rayap dibandingkan dengan partikel yang berat.

Bila dikaitkan dengan struktur dan sifat fisik ijuk yang dijumpai dalam penelitian ini , maka ijuk dapat dikatakan memiliki potensi sebagai perintang fisik serangan rayap tanah. Bentuk ijuk yang bervariasi dan sebagian besar berbentuk bulat memanjang dan bercabang-cabang serta menjalin satu sama lain berpotensi menghalangi penetrasi rayap. Hal ini juga didukung oleh sifat permukaan serat yang halus. Meskipun ukuran serat-serat penyusun ijuk secara individu jauh lebih kecil dibanding ukuran partikel efektif seperti yang dikemukakan Yanase et al. (2005), potensinya untuk dapat mencegah penetrasi rayap masih ditunjang oleh strukturnya yang menjalin dan dapat dibuat berlapis-lapis. Jalinan serat juga menciptakan lapisan yang membuat rayap sulit menembusnya karena celah yang ada sangat sempit sehingga tidak dapat dilewati oleh rayap. Efektivitas penyusunan bentuk jalinan dapat dilihat dari penggunaan kasa yang terbuat dari baja tahan karat (French, 1994) atau dari penggunaan film plastik (Fujimoto, 2004).

Berdasarkan penelitian laboratorium yang dilakukan oleh Irfan (2005) baik ijuk formasi alami maupun formasi pasaran memiliki efektivitas yang tinggi sebagai perintang fisik serangan rayap tanah Coptotermes sp. Dikemukakan pula bahwa tingkat efektivitas tersebut dipengaruhi oleh kerapatannya. Penggunaan ijuk dengan kerapatan 1,01 - 1,09 $\mathrm{g} / \mathrm{cm}^{3}$ mampu menghalangi serangan rayap tanah Coptotermes $s p$ dan menyebabkan $100 \%$ mortalitas pada pengujian laboratorium. 
Table 2. The average of fiber ramifications and their

\begin{tabular}{ccc}
\multicolumn{2}{c}{ distances } & \\
\hline & Ramification distance $(\mathrm{cm})$ \\
\cline { 2 - 3 } Ramifications & Natural & Marketed \\
& Formation & Formation \\
\hline $1^{\text {st }}-2^{\text {nd }}$ & 0.59 & 4.30 \\
$2^{\text {nd }}-3^{\text {th }}$ & 0.97 & 2.70 \\
$3^{\text {th }}-4^{\text {th }}$ & 1.00 & 0.80 \\
$4^{\text {th }}-5^{\text {th }}$ & 1.00 & - \\
\hline
\end{tabular}

\section{KESIMPULAN}

Struktur dasar jaringan ijuk yang terdiri atas serat-serat yang sebagian besar berbentuk bulat memanjang dan bercabang-cabang serta saling menjalin satu sama lain dengan permukaan yang halus berpotensi menghalangi penetrasi rayap. Penelitian tentang usaha-usaha pembentukan lembaran yang lebih seragam dan berlapis dengan kerapatan tertentu serta uji efektivitasnya di lapangan masih sangat diperlukan.

\section{UCAPAN TERIMA KASIH}

Penelitian ini dibiayai oleh Proyek Peningkatan Penelitian Pendidikan Tinggi, Direktorat Jenderal Pendidikan Tinggi Depdiknas. Terima kasih kepada Heru Arisandi atas bantuannya dalam persiapan penelitian ini.

\section{DAFTAR PUSTAKA}

French, J.R.J. 1994. Physical barrier and bait toxicants : The Romeo and Juliet of future
Termite Control. The International Research Group on Wood Preservation. 12p.

Fujimoto, H. 2004. A new type of barrier for subterranean termites using pliable plastic film. The $3^{\text {rd }}$ International Symposium on Surfacing and Finishing of Wood, November 24 - 25, Kyoto, Japan. Pp $404-411$.

Irfan, 2005. Efektivitas ijuk, tempurung kelapa, tempurung kemiri, batu gunung dan tanah sebagai perintang fisik alami serangan rayap tanah pada kayu. Skripsi Jurusan Kehutanan Fakultas Pertanian dan Kehutanan Universitas Hasanuddin, Makassar.

Rakhmawati. D. 1996. Prakiraan kerugian ekonomis akibat serangan rayap pada bangunan perumahan di Indonesia. Skripsi Jurusan Teknologi Hasil Hutan . Fakultas Kehutanan IPB. Bogor. (Tidak Diterbitkan).

Tarmadi, D dan S. Yusuf. 2004. Pengamatan penggunaan perintang fisik untuk penanggulangan rayap tanah di lapangan. Prosiding Seminar Nasional Masyarakat Peneliti Kayu Indonesia (MAPEKI) VII. 5-6 Agustus 2004. Makassar. p. A-132-137.

Yanase, Y., Y. Fujii, S. Okumura, T. Yoshimura, Y. Imamura, H. Kawaguchi, T. Okumura, 2005. Feasibility of several particulate materials as a physical barrier against termites. In: Proceedings of the $6^{\text {th }}$ International Wood Science Symposium LIPI - JSPS Core University Program in the Field of Wood Science, August 29 - 31 2005. Bali, Indonesia, pp 160-164.

Diterima : 17 Januari 2006

Astuti Arif, Musrizal Muin, dan Syahidah

Lab. Teknologi Hasil Hutan, Jurusan Kehutanan, Universitas Hasanuddin Kampus Tamalanrea, Jl. Perintis Kemerdekaan Km. 10, Makassar 90245 Telp./Fax. 0411-585917. Indonesia 